Available online on 15.04.2020 at http://jddtonline.info
Open Access to Pharmaceutical and Medical Research
unrestricted non-commercial use, provided the original work is properly cited

Open $\odot$ Access

Research Article

\title{
Wound Healing Activity of Calotropis Procera Root Bark on Diabetic Rats
}

\author{
Rohit P. Mali*, Priya S. Rao ${ }^{1}$, D.N. Vikhe ${ }^{2}$
}

Department of Pharmacognosy, Pravara Rural College of Pharmacy, Pravaranagar, Tal- Rahata Dist-Ahmednagar, India

\begin{abstract}
Herbal therapy and herbal medicine in traditional medicine as well as in alternative medicine practiced in the developed world. There is recent most of the harbal formulation are used to cure \& improve the humal life. The present study Wound healing activity of Calotropis procera root bark on diabetic rats in that root bark is extracted from ethanolic extract using soxhlet method. The pharmacognostic study was done after that phytochemical characters should be studied. The root bark has alkaloids, Flavonoids, steroids and tannins active constituents. Acute toxicity study carried out with three pharmacological models Incision model, Excision model, and Dead space model. All the extract show predominant activity against selected species. Extract shows beneficial effect on diabetic wound it heals in time with standard component. Overall results of this study reveals that this is an effective extract on diabetic wound.
\end{abstract}

Keywords: Traditional medicine, Calotropis procera, Wound Healing Activity

Article Info: Received 02 Feb 2020; Review Completed 17 March 2020; Accepted 23 March 2020; Available online 15 April 2020

\section{Cite this article as:}

Mali RP, Rao PS, Vikhe DN, Wound Healing Activity of Calotropis Procera Root Bark on Diabetic Rats, Journal of Drug Delivery and Therapeutics. 2020; 10(2-s):86-89 http://dx.doi.org/10.22270/jddt.v10i2-s.3955

*Address for Correspondence:

Rohit P. Mali, Department of Pharmacognosy, Pravara Rural College of Pharmacy, Pravaranagar, Tal- Rahata Dist-

Ahmednagar, India

\section{INTRODUCTION}

Man's existence on earth has been made possible only because of the vital role played by the plant kingdom in sustaining his life. Plants were being used as a source of medicine from the times immemorial as they were easily accessible as well as inexpensive they have provided the basis for the oldest medicinal systems of humanhistory. ${ }^{1}$

In present global scenario, natural medicines are gaining prominence, because they are economical, easily available and relatively free from side effects. The increased demand of the polyherbal formulation is reflective of positive impact of consolidated efforts aimed at reviving science of phytopharmacy. A large number of Indian medicinal plants are attributed with various pharmacological activities, because it contains diversified class of phyto-constituents. ${ }^{2}$

Calotropis procera is a flowering plant species having family Apocynaceae. It is native to Tropical Africa, North Africa, South Asia, Western Asia and Indochina. The green globes are hollow but contains a toxic milky sap. ${ }^{3}$

Calotropis procera Linn is small, erect and compact shrubs, which is used in several traditional medicines to cure various diseases. This shrub has been known to posses' Analgesic, Antitumor, Antihelmintic, Antioxidant, Hepatoprotective, Inflammatory, Antidiarrhoeal,
Anticonvulsant, Antimicrobial, Oestrogenic, Antinociceptive, and Antimalarial activity. A wide range of chemical compounds including- Benzoyllineolone, benzoylisolinelone and $B$-amyrin. The root bark contains the calotropoleanyl ester, proceroleanenol A and proceroleanenol B. The latex contains the calactin, calotropin, uscharin, sitosterol, and calotoxin..$^{4-9}$

Wound healing is a complex series of reactions and interactions among cells and "mediators." Diabetes mellitus is a condition which affects the person's ability to control their own blood sugar levels, either because their body doesn't produce enough insulin or because of insulin resistance when cells don't respond to the insulin that is produced. 10

In the present study we instigated wound healing activity of Calotropis procera root bark on diabetic rats Based on its ethnopharmacological profile and reputed medicinal use in traditional practice

\section{MATERAIL AND METHODS}

\subsection{Collections and drying}

Fresh root bark of Calotropis procera were collected from Shikago Hills, Khanapur, Pune district (Maharashtra).Dried plant material under shade dry was coarsely powdered in grinder and powder was used for extraction. 


\subsection{Extraction process}

The plant of Calotropis procera was collected. Then the dried root bark material is pulverized in grinder. The coarse powder was used for extraction.

Method: soxhelet extract

Solvents: Ethanol

- $\quad$ The dried root bark was crushed to powder.

- $\quad$ Calotropis procera root barks were extracted with Ethanol at $50^{0} \mathrm{C}$ temperature, for $16 \mathrm{hrs}$, in a $500 \mathrm{ml}$ round bottom flask.

- $\quad$ After 16 hrs of extraction, round bottom flask was cooled to room temperature and the extract were filtered and collected.

\subsection{Preliminary phytochemical screening for various} extracts:

\section{1) Test for carbohydrates:}

\section{a) Molisch test (General test ):}

Two ml of extract solution was added with few drops of 15 $\%$ methanolic alpha-naphthol solution in a test tube and $2 \mathrm{ml}$ of concentrated sulphuric acid was added carefully along the side of the test tube. The formation of reddish violet ring at the junction of two layers indicates the presence of carbohydrates.

\section{2) Test for reducing sugar:}

a) Benedict's test:

Mix equal volume of Benedict's reagent and extract solution in the test tube. Heat in a boiling water bath for $5 \mathrm{~min}$. solution appears green, yellow or red depending on amount of reducing sugar present.

b) Fehling's test:

Five $\mathrm{ml}$ of extract solution was mixed with $5 \mathrm{ml}$ fehling's solution (equal mixture of fehling's solution A and B ) and boiled. Development of brick red precipitated indicates the presence of reducing sugars.

\section{3) Test for Alkaloids:}

Evaporate all extracts separately. To residue, add dilute HCL. Shake well and filter. Use filtered solution for test.

a) Dragendroff's test:

2-3 ml test solution and $0.1 \mathrm{ml}$ Dragendroff's reagent was added in test tube. Formation of orange brown precipitate indicates the presence of alkaloids

b) Mayer's test:

2-3 ml test solution and $0.1 \mathrm{ml}$ of Mayer's reagent were added. Formation of yellowish buff precipitate indicates the presence of alkaloids.

c) Hager's test:

2-3 $\mathrm{ml}$ test solution and $0.1 \mathrm{ml}$ of Hager's reagent. Formation of yellowish precipitate indicates the presence of alkaloids.

d) Wagner's test:

2-3ml filtrate with few drops Wagner's reagent gives reddish brown ppt. e) Acid test:

Test solution treated with tannic acid solution gives buff coloured precipitate.

\section{4) Test for Flavonoids:}

a)Shinoda test:

To dry powder or extract, add $5 \mathrm{ml} 95 \%$ ethanol/t-butyl alcohol, few drops conc.HCL and $0.5 \mathrm{~g}$ magnesium turnings. Orange , pink, red to purple colour appears (flavonols, dihydro derivatives and xanthenes).

b ) Sulphuric acid test:

On addition of sulphuric acid (66\% or $80 \%)$ flavones and flavonols dissolve into it and a deep yellow solutions. Chalcones and aurones give red or red-bluish solutions. Flavanes give orange to red colours formed.

Addition of increasing amount of sodium hydroxide to the residue shows colouration, which decolourises after addition of acid.

Heat test solution with zinc and HCL, pink to red colour is observed.

\section{5) Test for Tannins:}

To 2-3 ml of aqueous or alcoholic extract, add few drops of following reagents.

a) $5 \% \mathrm{FeCl} 3$ solution: Deep blue-black colour.

b) Lead acetate solution: White ppt.

\begin{tabular}{|c|c|}
\hline Tests & Ethanolic extract \\
\hline \multicolumn{2}{|l|}{ Tests for Carbohydrates } \\
\hline Molisch"sTest & - \\
\hline Barfoeds Test & - \\
\hline \multicolumn{2}{|l|}{ Tests for Reducing Sugar } \\
\hline 1. $\quad$ Benedict's Test & - \\
\hline Fehling'sTest & + \\
\hline \multicolumn{2}{|l|}{ Test forAlkaloids } \\
\hline Dragendroff'sTest & + \\
\hline Mayer'sTest & + \\
\hline Hager'sTest & + \\
\hline Wagner's Test & + \\
\hline AcidTest & + \\
\hline \multicolumn{2}{|l|}{ Test for Flavonoids } \\
\hline ShinodaTest & + \\
\hline Sulphuric AcidTest & + \\
\hline \multicolumn{2}{|l|}{ Test for Tannins } \\
\hline Ferric ChlorideTest & + \\
\hline Dilute Nitric AcidTest & + \\
\hline
\end{tabular}

Note-'+ve' used for positive testand '-ve' used for negative test. The results of preliminary phytochemical study shows in Table No. presence of Alkkaloids, Flavoniods, Tannins, Glycosides, Proteins, Carbohydrate and Steroids 


\subsection{Pharmacological activity of extract}

\subsubsection{Acute toxicity study:}

The acute toxicity studies were carried out according to OECD guidelines - 425. Rats of either sex (three females and three males, weight: 25-35 g, age: 6-8 weeks) received ethanolic extract of Calotropis procera root bark starting at 2 $\mathrm{g} / \mathrm{kg}$ orally by gavage. The animals were observed for toxic symptoms continuously for the first $4 \mathrm{~h}$ after dosing. Finally, the number of survivors was noted after $24 \mathrm{~h}$ and these animals were then maintained for further 13 days with observations made daily.

\subsubsection{Animals}

The acute toxicity studies were carried out according to OECD guidelines -425 . Rats of either sex (three females and three males, weight: 25-35 g, age: 6-8 weeks) received ethanolic extract of Calotropis procera root bark starting at $2 \mathrm{~g} / \mathrm{kg}$ orally by gavage. The animals were observed for toxic symptoms continuously for the first $4 \mathrm{~h}$ after dosing. Finally, the number of survivors was noted after $24 \mathrm{~h}$ and these animals were then maintained for further 13 days with observations made daily.

\subsubsection{Induction of diabetes}

Diabetes was induced in animals by a single subcutaneous injection of the pancreatic b-cell toxin STZ (Sigma Chemical; freshly dissolved in sterile saline, $0.9 \%$ ) at a dose of 65 $\mathrm{mg} / \mathrm{kg}$ body weight. Using glucometer (Easy Gluco, Morepen Laboratories Ltd, New Delhi, India), blood glucose levels were monitored 3 days after STZ injection and throughout the duration of study to determine the hyperglycemic state of the animals. Animals that failed to develop average blood glucose concentration higher than $200 \mathrm{mg} / \mathrm{dl}$ were excluded from the study.

\subsubsection{Drug formulations and grouping of animals}

Two types of drug formulations were prepared for topical and oral administration of Calotropis procera extracts. For assessment of excision wound healing activity, Calotropis procera was formulated in ointment dosage form by using simple ointment BP as base. Ointment having $5 \%(\mathrm{w} / \mathrm{w})$ was applied where $2.5 \mathrm{~g}$ of Calotropis procera extract was incorporated in $50 \mathrm{~g}$ of simple ointment base BP.

For oral administration, two dose levels (100 and 200 $\mathrm{mg} / \mathrm{kg}$ ) were chosen from the previous studies. Grouping of animals for topical application (excision and incision wound model)

Group I served as diabetic control,

Group II treated with 5\% Calotropis procera ointment topically, Group III served as diabetic standard treated with framycetin ointment.

For oral administration (incision and dead space wound models), the animals were divided into three groups of six rats each

Group I served as diabetic control (vehicle treated),

Group II treated with Calotropis procera $(100 \mathrm{mg} / \mathrm{kg}$ ) orally,

Group III served as diabetic standard treated with Calotropis procera $(200 \mathrm{mg} / \mathrm{kg})$ orally.

Excision wound model

A standard wound of uniform $2 \mathrm{~cm}$ diameter was formed with the aid of a round seal (Morton and Melone, 1972). The percentage wound closure; epithelization time (Neuman and Logan, 1950) and scar area on complete epithelization were measured.

Incision wound model

Two para-vertebral straight incisions of $5 \mathrm{~cm}$ length each were made through the entire thickness of the skin, on either side of the vertebral column with the help of a sharp scalpel (Ehrlich and Hunt, 1969). After complete homeostasis the wound were closed by means of interrupted sutures placed at equidistance points about $1 \mathrm{~cm}$ apart. On the 7 th day sutures were removed and on the 10 th postwounding day tensile strength was measured by continuous water flow technique (Lee, 1968).

Dead Space wound model

The animals were divided into three groups of six rats each and kept in separate cages. The dead space wound was created by implanting subcutaneously polypropy lene tubes $(2.5 \mathrm{~cm} \times 0.5 \mathrm{~cm})$ in the lumbar region on dorsal side. Animals received Calotropis procera extract from 0 day to 9 th post-wounding day. On 10th post-wounding day, the granulation tissue harvested on each implanted tube was carefully dissected out along with the tube and employed for determination of breaking strength

\section{RESULT}

Table 3.1 Effect of topical application Calotropis procera on excision wound model

\begin{tabular}{|c|c|c|c|c|c|}
\hline \multicolumn{7}{|c|}{ Percentage of closure of excision wound area } & \multirow{2}{*}{$\begin{array}{c}\text { Epithelialization } \\
\text { in days }\end{array}$} \\
\hline Treatment & Day 4 & Day 8 & Day 12 & Day 16 & $27.85 \pm 2.42$ \\
\hline Diabetic control & $13.79 \pm 0.37$ & $29.53 \pm 0.43$ & $38.97 \pm 0.55$ & $57.05 \pm 0.72$ & $23.29 \pm 2.12^{*}$ \\
\hline Diabetic Standard & $18.82 \pm 0.35^{*}$ & $48.27 \pm 1.23^{*}$ & $66.13 \pm 0.50^{*}$ & $79.49 \pm 1.2^{*}$ & $20.84 \pm 2.19^{*}$ \\
\hline $\begin{array}{c}\text { Diabetic + Calotropis } \\
\text { proecra ointment }\end{array}$ & $19.96 \pm 0.49$ & $55.02 \pm 1.64$ & $70.32 \pm 0.62^{*}$ & $87.48 \pm 0.81^{*}$ & \\
\hline
\end{tabular}

Values are mean \pm SE. $n=6$ in each group. ${ }^{*} \mathrm{p}<0.01$ is compared to control

Table 13. Effect of topical application Calotropis procera on incision wound model (wound breaking strength in grams).

\begin{tabular}{|l|l|}
\hline Treatment & Wound breaking strength in gram \\
\hline Diabetic control & $199.87 \pm 4.86$ \\
\hline Diabetic Standard & $298.87 \pm 3.85^{*}$ \\
\hline Diabetic + Calotropis proecra ointment & $305.67 \pm 3.79^{*}$ \\
\hline
\end{tabular}

Values are mean \pm SE. $n=6$ in each group. ${ }^{*} \mathrm{p}<0.01$ is compared to control 
Table3.2. Effect of oral application Calotropis procera on incision wound model(wound breaking strength in grams).

\begin{tabular}{|l|l|}
\hline Treatment & Wound breaking strength in gram \\
\hline Diabetic control & $205.83 \pm 3.67$ \\
\hline Diabetic + Calotropis procera $(100 \mathrm{mg} / \mathrm{kg})$ & $305.88 \pm 3.47^{*}$ \\
\hline Diabetic + Calotropis procera $(100 \mathrm{mg} / \mathrm{kg})$ & $341.67 \pm 3.54^{*}$ \\
\hline
\end{tabular}

Values are mean \pm SE. $n=6$ in each group. ${ }^{*} \mathrm{p}<0.01$ is compared to control

Table 3.5 Effect of oral application Calotropis procera on dead space wound model

\begin{tabular}{|l|l|l|}
\hline Treatment & Granuloma breaking strength (g) & Granuloma tissue dry weight (1 g/100 g) \\
\hline Diabetic control & $358.85 \pm 29.23$ & $48.37 \pm 3.29$ \\
\hline $\begin{array}{l}\text { Diabetic + Calotropis procera } \\
(100 \mathrm{mg} / \mathrm{kg})\end{array}$ & $478.39 \pm 41.78^{*}$ & $68.85 \pm 2.08^{*}$ \\
\hline $\begin{array}{l}\text { Diabetic }+ \text { Calotropis procera } \\
(100 \mathrm{mg} / \mathrm{kg})\end{array}$ & $503.54 \pm 42.43^{*}$ & $81.53 \pm 1.91^{*}$ \\
\hline
\end{tabular}

\section{DISCUSSION}

The phytochemical study of the plant Calotropis procera revealed the presence of various active constituents such as alkaloids, flavonoids, steroids, and tannins. The Diabetic wound healing activity was determined by using animal model. The activity of extract may be due to presence of active constituent present in the Root bark of Calotropis procera.

Topical application of Calotropis procera. in excision wound model increased the percentage of wound contraction. Scar area and epithelization time were decreased. In incision wound and dead space wound breaking strength of wounds and hydroxyproline was increased. Deposition of newly synthesized collagens at the wound site increases the collagen concentration per unit area and hence the tissue tensile strength. In dead space model there was a significant increase in granuloma tissue breaking strength in extract treated groups in dead space wound model. The higher breaking strength indicates better healing of wounds. Higher hydroxyproline content was seen with extract treatment. The increased amount of hydroxyproline in test groups underlines increased collagen content, since hydroxyproline is the direct estimate of collagen synthesis it supports the wound healing activity of Calotropis procera. ${ }^{11}$ Recent studies have shown that phytochemical constituents like flavonoids and triterpenoids are known to promote the wound healing process mainly due to their astringent and antimicrobial properties, which appear to be responsible for wound contraction and increased rate of epithelialization. The preliminary phytochemical analysis of the Calotropis procera root bark extract showed the presence of tannins, flavonoids, triterpenoids, and alkaloids. Any one of the observed phytochemical constituents present in Calotropis procera may be responsible for the wound healing activity. 12

Calotropis procera accelerated wound healing activity of diabetic rats and thus supports its traditional use.

\section{REFERENCES}

(1) Beyene, B.; Beyene, B.; Deribe, H. Review on Application and Management of Medicinal Plants for the Livelihood of the Local Community. J. Resour. Dev. Manag.2016; 22, 33-39.

(2) Khatri, A.; Garg, A.; Agrawal, S. S. Evaluation of Hepatoprotective Activity of Aerial Parts of Tephrosia Purpurea L. and Stem Bark of Tecomella Undulata. J. Ethnopharmacol.2009; 122 (1), 1-5. https://doi.org/10.1016/j.jep.2008.10.043.

(3) Kirtikar, K. R. Indian Medicinal Plants : By K.R. Kirtikar, B.D. Basu, and An I.C.S. In 4 Volumes.; Lalit Mohan Basu: Allahabad, 1935.

(4) Verma, S. PHARMACOLOGICAL PERSPECTIVES OF CALOTROPIS GIGANTEA (ASCLEPIADACEAE) Sunita Verma. Int. J. Pharmacogn.2016; 3 (9), 405-409. https://doi.org/10.13040/IJPSR.0975-8232.IJP.3(9).405-09.

(5) WATT, J. M.; BREYER-BRANDWIJK, M. G. The Medicinal and Poisonous Plants of Southern Africa: Being an Account of Their Medicinal Uses, Chemical Composition, Pharmacological Effects and Toxicology in Man and Animal; E. \& S. Livingstone Ltd.: 1617, Teviot Place, Edinburgh, 2008; Vol. 132. https://doi.org/10.1038/132336a0.

(6) Al-Qarawi, A. A.; Mahmoud, O. M.; Sobaih, M. A.; Haroun, E. M.; Adam, S. E. I. A Preliminary Study on the Anthelmintic Activity of Calotropis Procera Latex against Haemonchus Contortus Infection in Najdi Sheep. Vet. Res. Commun.2001; 25 (1), 61-70. https://doi.org/10.1023/A:1026762002947.

(7) Saxena, A.; Bhagat, M.; Arora, J. In Vitro Cytotoxicity of Extracts and Fractions of Calotropis Procera (Ait.) Roots against Human Cancer Cell Lines . Int. J. Green Pharm.2010, 4 (1), 36. https://doi.org/10.4103/0973-8258.62165.

(8) Waheed, N.; Jabeen, K.; Iqbal, S.; Javaid, A. BIOPESTICIDAL ACTIVITY OF Calotropis Procera L. AGAINST Macrophomina Phaseolina. African J. Tradit. Complement. Altern. Med. AJTCAM2016, 13 (6), 163-167.

https://doi.org/10.21010/ajtcam.v13i6.23.

(9) Kumar, V. L.; Basu, N. Anti-Inflammatory Activity of the Latex of Calotropis Procera. J. Ethnopharmacol.1994, 44 (2), 123-125. https://doi.org/https://doi.org/10.1016/03788741(94) $90078-7$

(10) Deshmukh, P. T.; Gupta, V. B. Embelin Accelerates Cutaneous Wound Healing in Diabetic Rats. J. Asian Nat. Prod. Res.2013, 15 (2), 158-165. https://doi.org/10.1080/10286020.2012.758634.

(11) Deshmukh, P. T.; Fernandes, J.; Atul, A.; Toppo, E. Wound Healing Activity of Calotropis Gigantea Root Bark in Rats. J. Ethnopharmacol.2009, 125 (1), 178-181. https://doi.org/10.1016/j.jep.2009.06.007.

(12) Rasik, A. M.; Raghubir, R.; Gupta, A.; Shukla, A.; Dubey, M. P.; Srivastava, S.; Jain, H. K.; Kulshrestha, D. K. Healing Potential of Calotropis Procera on Dermal Wounds in Guinea Pigs. J. Ethnopharmacol.1999, 68 (1-3), 261-266. https://doi.org/10.1016/S0378-8741(99)00118-X 